\title{
Polyclonal antibodies against isoflavones: fast screening method for Forage legume species
}

\author{
J. F. Farias ${ }^{1 \mathrm{a}}$, K. M. R. Duarte ${ }^{\text {lb }}$, L. H. Gomes ${ }^{2}$, F.F.Pessoa ${ }^{\text {lc }}$, \\ A. J. F. de $\mathrm{Melo}^{3}$, J. A. P Savisky ${ }^{1 \mathrm{~d}}$ \\ (1 CPDNAP - Instituto de Zootecnia - Rua Heitor Penteado, 56 Nova Odessa, SP Brazil.CEP 13460-000,) \\ (2 USP-ESALQ-Av. Pádua Dias 11, Piracicaba, SP 13418-900) (3-Faculdades Anhanguera-Leme-SP)
}

\begin{abstract}
Isoflavones are phytoestrogens widely used by industry for its beneficial effects as estrogens mimicked. The isolation of isoflavones are done from soybean and research one or more sources of isoflavones means biodiversity and sustainability, leaving soybean as a protein source for animal and human feeding. This study aimed to develop polyclonal antibodies to identify isoflavones in different leguminosae species, from a Tropical Forage Genebank, optimizing an immunoenzymatic assay. Our results indicate antibodies produced are highly sensitive and specific to isoflavones and can be used to screen plants with isoflavones in fast and easy method .
\end{abstract}

Keywords: ELISA, isoflavones, leguminous species, polyclonal antibodies, vegetal biodiversity.

\section{INTRODUCTION}

Isoflavones are phytoestrogens with numerous properties. In mammals and fish, those phytoestrogen can bind to oestradiol receptors (Bennetau-Pelissero, 2001), property that can be used for hormonal natural treatments. Isoflavones include genistein, daidzein and glycitein. Great number of other vegetables are also known to contain such compounds, mainly plants from leguminous family. Commercially, isoflavones are extracted from soybean (Glycine max), which is rich in phytoestrogens and especially in genistein (Park, 2001) and the effects as antioxidant action, anti-fungi activity, anticancer and estrogenic activity are some among several characteristics of this aglicone substances (PARK, 2001). Vieira et al (2007) verify the effects caused by the use of estrogen and isoflavones, done by women in the menopause phase., where the women were separated into two groups: one using estrogen and other using isoflavones or placebo. By the end of six months, all women were evaluated by physical examination and all responding to a quiz about life quality, from MENQOL, which is linked to points. Both groups showed a better life quality, decreasing the menopause symptoms', concluding the use of isoflavones contribute to the better life quality of women. Uesugi, et al (2002) evaluated the benefits of isoflavones as supplementation food, for women using $61.8 \mathrm{mg}$ of isoflavone daily. Blood samples were used to measure triglycerides, total and LDL cholesterol. In their urine, isoflavones were identified by HPLC and boné thickness was measured. Results show isoflavones can reduce the risks of osteoporosis and cardiovascular problems in women post-menopause. Previously Lamartiniere, et al (1995) studied the anticancer activity of genistein, for skin cancer in mice. After 30 days of isoflavone administration, there were na increase of antioxidant enzymes in the skin and intestine, allied to oncogeneses inhibition, facts that did not occur in the lower doses groups.

The identification and quantification of isoflavones is a need to search for new sources of this compound, in order to substitute soybean as the major source, once it is a rich and valuable food for humans and livestock. In this way, several immunoassays have been optimized to detect the presence of isoflavones in vegetal tissues (Bennetau-Pelissero et al, 2003). Since we have a great biodiversity of leguminous species, kept in a gene bank, it is necessary to develop a fast and simple method for a screening of potential species, hiding isoflavones into their seeds. Immunoassays are already used to identify isoflavones in biological fluids, vegetal and food (WU et al., 2004). Shinkaruk et al, (2008) developed a immune test based upon ELISA to verify the presence of glicitein in food, soy-based food and blood plasma from women whose consumed those food and supplementation. The ELISA showed several advantages, as easy-to-do method, fast and allows a minimum time consuming for a great samples number. Besides that, it has a lower cost in comparison HPLC or RIA. The ELISA was suitable for glicitein analysis in soy based food and supplementary food and for verifying glicitein amount in blood plasma. Barbosa et al (2006) evaluated isoflavones rates and its anti-oxidant capability from soybean and report the seed processing can alters the results. From several samples, the protein samples showed higher aglicones amounts, due to the processing system, where the $\beta$-glicosidases enzymes can lead to hydrolyses the $\beta$-glicosideous and transforming it to aglicones. Park et al (2001) studied the biotechnological application of enzymatic conversion of isoflavones with higher biological activity, using grinded and non fat soy beans, exposed to microorganisms activity during fermentation process. Those process increased on 27 times the amount of isoflavones disable, in other words, the fermentation process turned glicosilate isoflavones forms into aglicones.

The Forage Gene Bank in the Institute of Animal Science and Pastures (IZ) keeps 276 legume species, most of it understudied about protein amounts and secondary metabolites. In this way, this work characterizes such biodiversity regarding its isoflavone amounts, by polyclonal production used on an Enzyme immunosorbent Assay, that have low cost, high sensitivity and specificity. 


\section{MATERIAL AND METHODS}

Anti-sera production: Two females 45 days-old New Zealand Rabbits were used to produce polyclonal antibodies. Immunogen was prepared bioconjugating isoflavone to carbodiimides (Hermanson, 1988). Immunizations were performed each 15 days, according to methodology previously described (Duarte et al, 2007). Blood were tittered using sera from ear punction, before each immunization. At the end of five immunizations, best responding rabbit was bled and sera were kept at $-80{ }^{\circ}$ C.Plate trapped antigen-ELISA were optimized as described in CROWTHER (2009). For these assays, sera dilution, antigen dilution, reagents concentration and enzymatic assay were evaluated.

Species used: To explore the presence of isoflavones in other legume species, a Tropical Forage Gene Bank provide seeds from a large number of legume species, kept for it is potential on protein content, used as protein bank in livestock production systems. Pilot tests were done using five leguminous species from Institute of Animal Science and Pastures, Forage Gene Bank: Neonotonia wightii, Canavalia ensiformis, Glycine max, Calopogonium mucunoides, Crotalaria juncea, Mucuna Deeringiana, Stizolobium aterrimum and Leucena palida

Extraction Treatment: Seed were grinded in domestic mill and submitted to hydrothermal treatment of $50{ }^{\circ} \mathrm{C}$ for 12 hours, then ventilated dried. Isoflavones extraction were performed with $100 \mathrm{mg}$ of dried sample, $4 \mathrm{~mL}$ of methanol and 0.1 $\%$ of acetic acid, under shaking at each 15 minutes for 5 hours, room temperature. Supernatant were used for immunoassays (Carrão-Panizzi, et al, 2003; Genovese \& Lajolo, 2001).

PTA- ELISA tests: Enzyme assays were performed according to Crowther (2009), with some adaptations. Antigen (100 ul of seed suspension) were placed into micro wells, in triplicates, incubated overnight at $4{ }^{0} \mathrm{C}$. Blocking were done using PBS buffer added to $1 \%$ BSA (bovine sera albumin, fraction V) for one hour at $37{ }^{\circ} \mathrm{C}$. Plates were dried and anti-sera dilution (1:500) were placed, for another one hour at $37{ }^{\circ} \mathrm{C}$. Plates were three times washed (PBS, Tween $200,05 \%$ and 0,25 $\%$ Gelatin) and anti-rabbit conjugated HRP sera was added. After one hour at $37{ }^{\circ} \mathrm{C}$, plates were three times washed (PBS-TG) and OPD revealed, at $480 \mathrm{~nm}$ (Carrão-Panizzi, et al, 2003; Genovese and Lajolo, 2001).

\section{RESULTS AND DISCUSSION}

Sera titration can be seeing at Figure 1 demonstrating the sera harvesting at each 15 days, before each new immunization and once the two rabbits showed not similar titer, only rabbit 2 was bled, the sera separated by centrifugation and kept into $100 \mathrm{uL}$ aliquots, at $-80{ }^{\circ} \mathrm{C}$.

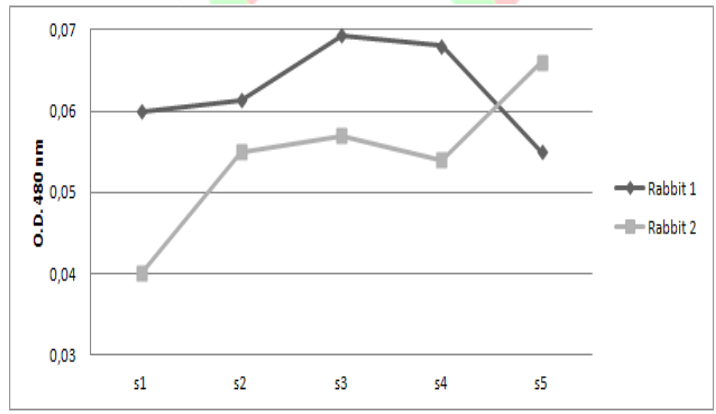

Figure 1: PTA- ELISA titer from rabbits, during immunization period. S1: after 15 days of first immunization. Sequential blood collection each 15 days, until S5 (75 days).

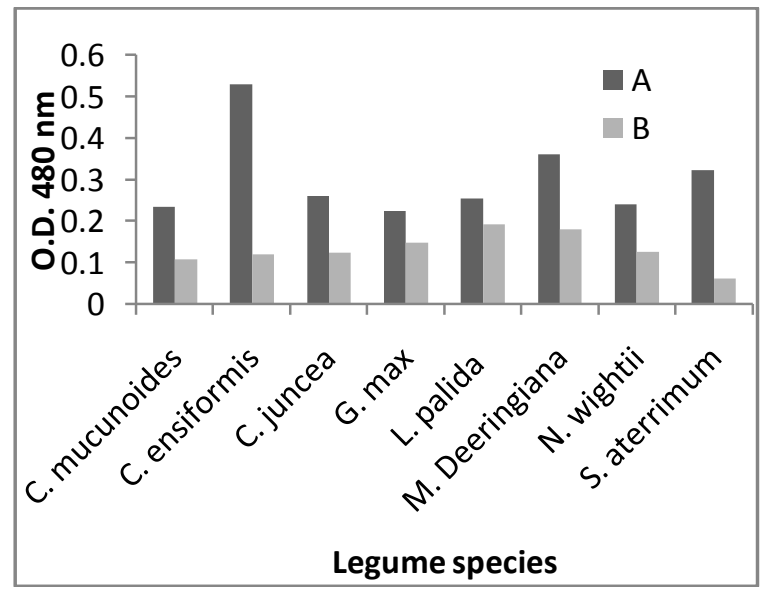


Figure 2: PTA-ELISA titer of isoflavone concentration in eight legume species after extraction protocols: (A) hydrothermal treatment; (B) no treatment.

Seeds from the eight legume species from the Forage Gene Bank were used as immunogen in the ELISA screening test. Explore the vegetal biodiversity leads to best use of natural resources as well as amplify the range of pharmacological compounds, in the isoflavone case, mainly dependent on soybean commercial specie. All seeds received hydroalcoholic and thermal extraction. Results (Figure 2) were similar to those obtained Carrão-Panizzi, et al (2003) that tested different hydrolysis temperatures for hydrothermal treatments $\left(50^{\circ} \mathrm{C}, 60^{\circ} \mathrm{C}\right.$ and $\left.80^{\circ} \mathrm{C}\right)$ with higher isoflavones aglicones amount at $50^{\circ} \mathrm{C}$ for 12 hours, where the malonil isoflavone form decreases and the aglicone forms increases. Genovese and Lajolo (2001) tested methanol (70\% and 80\%) and acetonitrile (60\% and 80\%) for isoflavone extraction from soy as soy flour, protein extract and texturized protein and the results shown methanol at 70 or $80 \%$ had the same yield extraction but the methanol $80 \%$ decreased the contaminants, considered ideal for isoflavone extraction. The species were chosen by it is seed production, which is high and the species are well adapted to tropical clime and the management of those species are known and well described by literature. All the seven species showed higher isoflavone content in comparison to Glycine max (Soybean). Such results can revealed a potential source on different legume species for general isoflavone forms, to be explore on pharmaceutical research as natural products for women's health.

\section{CONCLUSION}

Results are preliminary but indicate the possible use of other legume plants as isoflavone source. The characterization of biodiversity aiming a pharmaceutical use can be a sustainable choice for environment purpose and for natural source of phytohormones.

\section{ACKNOWLEDGEMENTS}

To CAPES, for the scholarship and to the Institute of Animal Science and Pastures, for the Forage Gene bank accesses.

\section{REFERENCES}

[1]. $\quad$ A.C.L. BARBOSA, et al. Teores de isoflavonas e capacidade antioxidante da soja e produtos derivados. Ciência e Tecnologia de Alimentos, v. 26, n. 4, 2006, 921-926.

[2]. C. BENNETAU-PELISSERO,et al. ELISA as a new method to measure genistein and daidzein in food and human fluids, Food Chemistry ,82, 2003, 645-658.

[3]. C. BENNETAU-PELISSERO, et al. Effect of genistein-enriched diets on the endocrine process of gametogenesis and on reproduction efficiency of the rainbow trout Oncorhynchus mykiss, General and Comparative Endocrinology, 121, 2001, 173-187.

[4]. C.A. LAMARTINIERE, et al. Neonatal genistein chemopreventives mammary cancer. Proceedings of the Society for Experimental Biology and Medicine. 208 (1), 1995,120-123.

[5]. I.C. CÉSAR, et al. Determinação de daidzeína, genisteína e gliciteína em cápsulas de isoflavonas por cromatografia em camada delgada (CCD) e cromatografia líquida de alta eficiência (CLAE). Revista Brasileira de Farmacognosia, v. 17, n. 4, out/dez. 2007, 616-625.

[6]. J.R. CROWTHER, The ELISA guidebook, in Series Springer Protocols, Methods in Molecular Biology, 516 (New Jersey: Human Press, 2009) 566 p.

[7]. $\quad$ K.M.R. DUARTE, Protocolo e Normas para Uso de Animais de Laboratório para Produção de Anticorpos e Soros. Boletim de Indústria Animal, 64 (2), 2007, 167-177.

[8]. $\quad$ L.H.L. VIEIRA, et al. Effects of isoflavone and conjugated equine estrogen on the postmenopausal quality of life. Rev. Bras. Ginecol. Obstet.29(5), 2007, 248-52.

[9]. M.C.CARRÃO-PANIZZI, et al. Efeitos de genótipos, ambientes e de tratamentos hidrotérmicos na concentração de isoflavonas agliconas em grãos de soja. Pesq. agropec. Bras. v.38, n. 8, Ago, 2003, p. 897902.

[10]. Q.WU, M. WANG and J.E. SIMON, Analytical methods to determine phytoestrogenic compounds. Journal of Chromatography B, 812, 2004, 325-355.

[11]. S. SHINKARUK, et al. Synthesis of Haptens and Conjugates for ELISA of Glycitein: Development and Validation of an Immunological Test. J. Agric. Food Chem. 56, 2008, 6809-6817.

[12]. T.UESUGI, et al. Beneficial Effects of Soybean Isoflavone Supplementation on Bone Metabolism and Serum Lipids in Postmenopausal Japanese Women: A Four-Week Study. Journal of the American College of Nutrition, 21(2), 2002, 97-102.

[13]. Y.K.PARK, et al. Biotransformações de isoflavonas de soja. Biotecnologia Ciência \& Desenvolvimento, 20, 2001, 12-14. 